\title{
STUDENTS' VOCABULARY MASTERY THROUGH ENGLISH SONGS AT MADRASAH ALIYAH NEGERI 1 HALMAHERA UTARA
}

\author{
Saiful Latif ${ }^{1}$, Mardia A. Rahmanl ${ }^{2}$ \\ ${ }^{1}$ Program Studi Pendidikan Bahasa Inggris, FKIP Universitas Khairun, Indonesia \\ ${ }^{2}$ Program Studi Pendidikan Fisika, FKIP Universitas Khairun, Indonesia \\ saiful.latif@gmail.com; mardia.rahman01@gmail.com
}

\begin{abstract}
The aim of this research is to know the extent to which the use of English song improves students' vocabulary at Madrasah Aliyah Negeri 1 Halmahera Utara. This research was quantitative research by using pre-experimental design with one group pretest-posttest. The sample of this research was 20 students in class X-3 Social science students by using convenience sampling technique. The instrument used in the research was the song lyrics. The students' answer the question by determining noun, verb and adjective of vocabulary consisting of 50 items. The data were analyzed by using t-test. It was found that teaching vocabulary by using English Song helped the students to master vocabulary. Based on the data analysis, teaching by using English Song could significantly improve students' vocabulary.The research shows the score of pre-test and posttest as follow: pretest 58.9 score and posttest 75.1 score, and T-count value obtain 12.7 and $t$ critic 1.729 at the significant level 0.05 . It means $t$-count is higher that $t$-critic. The null hypothesis (H0) stating that teaching vocabulary through English song cannot improve students vocabulary is rejected and the alternative hypothesis (Hi) stated that teaching vocabulary through English song can improve students' vocabulary mastery at Madrasah Aliyah Negeri 1 Halmahera Utara is accepted.
\end{abstract}

Keywords: Improving, Vocabulary Mastery, English Songs.

\section{INTRODUCTION}

Many cases now when the researcher observed in MAN Halmahera Utara at first grade students show that many students lack of vocabulary especially when they hear teacher says they can not get the point and they can not understand it. So, the teacher combine the English language and Indonesia to make them understand what the teacher says. The teacher of the school also teaches monotonuously to the students full of the text on the book so make the students feel bored and not interest to study English language especially in the vocabulary. So the researcher intends to solve the problems through English song to improve students' vocabulary.

So the researcher intends to know the influence of song in improving their vocabulary mastery by conducting the research with the title "Improving students' vocabulary mastery through English song at MAN Halmahera Utara".

\section{Listening}

Listening is an essential skill, present in most of the activities we carry out throughout our lives (Rodriguez,2012:10). By the definition, listening is a process of understanding the spoken language in receiving the languages through the ears.

\section{The Important of Listening}

According to Rodriguez (2012:12), Contrary to what everybody thinks about foreign language learning, listening competence is wider than speaking competence. This is the reason why; recently, the language teaching profession has brought into focus on listening comprehension. Vocabulary

Morgan and Rinvolucri, (2004: 7) claim that the acquisition of vocabulary is a social process rather than a solitary one. We expand our understanding of word meanings by interchanging and sharing it with other'. The first step when someone learns foreign language is to know vocabulary, so people must know vocabulary itself.

Based on the above experts' statements about vocabulary, the researcher concludes that 
vocabulary is the important thing of English that should be known by the people if they want to speak, because to speak needs vocabulary to arrange it to be a sentence.

\section{The Importance of Vocabulary}

According to Thornburry (2002: 13), without grammar very little can be conveyed but without vocabulary nothing can be conveyed. While Allen (1983: 2) states that Learners often believed that all they needed was a large number of words. They thought they could master the language by learning a certain number of English words. So, vocabulary is really important because it is main key to understand more about English.

\section{Teaching and Learning English by Using Song}

Song and teaching learning is three aspects that relate each other because song could make teaching and learning become easy and relax. Besides that, song can improve several skills of English that one of them is vocabulary. Millington (2011: 134) Songs play an important role in the development of young children learning a second language. A testament to this is the frequency with which songs are used in English Language Teaching classrooms all over the world. This paper begins by looking at why songs can be considered valuable pedagogical tools. In particular, it will discuss how songs can help learners improve their listening skills and pronunciation, and how they can be useful in the teaching of vocabulary and sentence structures.

\section{The Steps of Teaching English by Using Song}

Shin and Crandall ( 2017: 19), Step for teaching songs to YLs

- Introduce the topic of the song.

- Review the vocabulary students already know.

- Pre-teach the new vocabulary.

- Listen to the song (with the teacher singing, or with an audio recording or video).

- Teach the song line by line.

- If there are multiple verses and a refrain, follow these steps: Teach the refrain line by line.

- Teach the tune of the verse using "la lala" instead of the lyrics (be sure to add the refrain with the lyrics at the end of the verse).

- Teach the verses one by one, always singing the refrain after each one.

- Point out words that rhyme at the end of each line and practice repeating them when teaching each verse.

\section{RESEARCH METHOD}

This research apply quantitative method because the researcher expects to teach in the class using song and then make a test to know students' improvement of vocabulary.

This research uses pre-experimental using pre-test-post-test design as the research design, this design is as follows:

\section{$\mathrm{O}_{1} \times \mathrm{O}_{2}$}

Where:

$\mathrm{O}_{1} \quad=$ the result of pre-test (before giving treatment)

$\mathrm{X}=$ in the treatment by using song in teaching vocabulary noun, verb and adjective.

$\mathrm{O}_{2}=$ the result of post-test (after giving treatment by using song in teaching vocabulary/ noun, verb and adjective) 
Sample is a half of the population that the researcher conducted the research with experimental. Sugiono (2016:118) states sample is a part of number and characteristic that is possessed on population. Kothari (2004:56) says the size of the sample, Sample design is determined before data are collected. In which respondents are chosen based on their convenience sample.The researcher used convenience sampling that consists of 20 students in the class X/3 IPS of MAN 1 Halmahera Utara.

The instrument in this research is about the English song. The researcher provides the English songs with the lyrics and asks students to determine the noun, verb, and adjectiveby theEnglish song they have listened.

There are two tests administered to the students namely pretest and posttest to know students' pre-test before treatment and after treatment, the tests are pre-test and post-test, the researcher will determine how many noun, verb and adjective in a song. If students determine all vocabulary true, they will obtain 100 score:

$$
\mathrm{N}=\frac{\text { Getscore }}{\text { scoremaximum }} \times 100
$$

The above formula is for counting the students' score based on their answer in every song. In analysis the data, the researcher will use dependent-test is sample form to compare the result serve in the produce of the formula as follows:

$$
t=\frac{\bar{D}}{S \bar{X} D}
$$

Where:

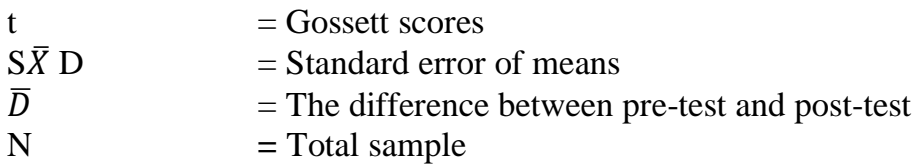

To analyze the formula above, the researcher intends to show the formulas as follow:

1. Counting the difference between $\mathrm{x}_{1}$ and $\mathrm{x}_{2}$

$\mathrm{D}=\frac{\sum \mathrm{X}}{\mathrm{N}}$

2. Counting standard deviation of the difference

$\mathrm{SD}=\sqrt{\frac{\mathrm{SS}}{\mathrm{N}}}$ Where $\mathrm{SS}=\sum \mathrm{X} 2-\frac{\left(\sum \mathrm{X}\right) 2}{N}$

3. Counting standard error of means

$\mathrm{SEx}=\frac{\mathrm{SD}}{\sqrt{\mathrm{N}-1}}$

4. Counting t-score

$\mathrm{t}=\frac{\mathrm{X}}{\mathrm{SXD}}$

Where:

X : Any score 
$\sum \quad:$ The sum of add them up

$\underline{\underline{X}} \quad:$ The sum of all the scores

$\overline{\mathrm{X}} \quad$ : The mean or arithmetic average, of the score

$\mathrm{N} \quad$ : Total number of subjects

$\sum \mathrm{X}^{2} \quad$ : The sum of all the squares. Squares each scores and add up all the squares

$\left(\sum X\right)^{2}$ : The squares of the sum, add up all the scores and squares the sum

(Gay, 2012)

\section{FINDING AND DISCUSIONS}

\section{Findings}

The findings consist of the Students' Score of pretest and posttest, the result of analyzing data, the mean score and standard deviation of the students' pretest and posttest, t-test value of students' vocabulary achievement.

1. Comparing between Data of the Pretest and Posttest Result

Table 1. Comparing between Data of the pretest and Posttest Result

\begin{tabular}{lccccc}
\hline No & Respondents & Posttest $\left(\mathbf{X}_{\mathbf{2}}\right)$ & Pretest $\left(\mathbf{X}_{\mathbf{1}}\right)$ & $\mathbf{D}$ & $\mathbf{D}^{\mathbf{2}}$ \\
\hline $\mathbf{1}$ & Y & 76 & 58 & 18 & 324 \\
$\mathbf{2}$ & AH & 82 & 64 & 18 & 324 \\
$\mathbf{3}$ & NBA & 62 & 44 & 18 & 324 \\
$\mathbf{4}$ & SS & 82 & 68 & 14 & 196 \\
$\mathbf{5}$ & NJ & 68 & 58 & 10 & 100 \\
$\mathbf{6}$ & KR & 82 & 66 & 16 & 256 \\
$\mathbf{7}$ & TA & 62 & 50 & 12 & 144 \\
$\mathbf{8}$ & TMA & 80 & 62 & 18 & 324 \\
$\mathbf{9}$ & H & 84 & 66 & 18 & 324 \\
$\mathbf{1 0}$ & S & 72 & 58 & 14 & 196 \\
$\mathbf{1 1}$ & JI & 80 & 66 & 14 & 196 \\
$\mathbf{1 2}$ & SNI & 68 & 50 & 18 & 324 \\
$\mathbf{1 3}$ & SWA & 78 & 60 & 18 & 324 \\
$\mathbf{1 4}$ & AJ & 70 & 52 & 18 & 324 \\
$\mathbf{1 5}$ & AAR & 84 & 68 & 16 & 256 \\
$\mathbf{1 6}$ & NS & 72 & 58 & 14 & 196 \\
$\mathbf{1 7}$ & ISA & 66 & 48 & 18 & 324 \\
$\mathbf{1 8}$ & UAHS & 80 & 62 & 18 & 324 \\
$\mathbf{1 9}$ & HFP & 72 & 54 & 18 & 324 \\
$\mathbf{2 0}$ & MMFMK & 82 & 66 & 16 & 256 \\
\hline
\end{tabular}

\section{Analysis of the Data of Pretest and Posttest}

The researcher used dependent t-test analysis because the researcher just took one group in this research, the formula is as follow:

1. Counting the differences between $X_{1}$ and $X_{2}$

$$
\begin{aligned}
\mathrm{X} & =\frac{\sum \mathrm{X}}{\mathrm{N}} \\
\mathrm{X} 1 & =\frac{1.178}{20} \\
& =58.9
\end{aligned}
$$




$$
\begin{aligned}
\mathrm{X} 2 & =\frac{1.502}{20} \\
& =75.1 \\
\mathrm{D} & =\frac{\sum \mathrm{D}}{\mathrm{N}} \\
& =\frac{324}{20} \\
& =16.2
\end{aligned}
$$

2. Counting standard deviation of the difference

$$
\begin{aligned}
& S D=\sqrt{\frac{S S}{N}} \text { Where } S S=\sum X 2-\frac{\left(\sum X\right) 2}{N} \\
= & \sqrt{\frac{5.360}{20}}-16.2^{2} \\
= & \sqrt{268-262.44} \\
= & 5.56
\end{aligned}
$$

3. Standard error of means

$$
\begin{aligned}
\text { SEx } & =\frac{S D}{\sqrt{\mathrm{N}-1}} \\
& =\frac{5.56}{\sqrt{19}} \\
& =\frac{5.56}{4.35} \\
& =1.27
\end{aligned}
$$

4. Counting t-score

$$
\begin{aligned}
t & =\frac{D}{S X D} \\
& =\frac{16.2}{1.27} \\
& =12.7
\end{aligned}
$$

\section{Mean and Standard of Deviation of the Students}

The mean score of standard deviation of students' pretest and posttest is presented in following:

Table 2. Mean Score, standard Deviation, Standard Error of mean of Pretest and Posttest.

\begin{tabular}{lllll}
\hline Test & Mean score & Standard Deviation & $\begin{array}{l}\text { Standard } \\
\text { Mean }\end{array}$ & Error of \\
\hline Pretest $\left(\mathrm{X}_{1}\right)$ & 58.9 & 5.56 & 1.27 & \\
Posttest $\left(\mathrm{X}_{2}\right)$ & 75.1 & & & \\
\hline
\end{tabular}

The above table shows that the mean score of students' pretest is 58.9 and the mean score posttest is 75.1. The standard deviation is 5.56. The standard error of mean is 1.27.

\section{T-Statistical}

In order to know difference between pretest and posttest is statistically significant, the ttest statistical analysis. The result of the t-statistical is 12.7 . 
Table 3. T-statistical and Critical Values

\begin{tabular}{lll}
\hline Variable & T-statistical & T- Critical Value \\
\hline X/3-IPS & 12.7 & 1.729 \\
\hline
\end{tabular}

If $\mathrm{t}$-count $>\mathrm{t}$-critic, so (Ha) is accepted and $(\mathrm{H} 0)$ is rejected.

If $\mathrm{t}$-count $<\mathrm{t}$-critic, so (Ha) is rejected and ( $\mathrm{H} 0)$ is accepted.

\section{Hypothesis testing}

The research applied dependent t-test on the hypothesis test at 0.05 level of significance and the formula for degree of freedom (df) is $\mathrm{N}-1$, the number pairs minus one. To find out degree of freedom (df) the research using the following formula:

$\mathrm{df}=\mathrm{N}-1$

$\mathrm{df}=20-1$

$\mathrm{df}=19$

There is significant difference between pretest and posttest of the students' vocabulary before and after teaching by using song. For degree of freedom (df) is 19 and level of significance 0.05 .

\section{Discussion}

This research found students' vocabulary understanding before giving treatment was low. There is not student obtained excellent score (90-100) and very good score, nine students obtained adequate score (61-70), seven students obtained poor score (51-60), four students obtained very poor score (less than 50). After treatment, students' vocabulary got developing.

In posttest, there are eight students obtained good score, six students obtained very good score, six students obtained adequate score but no student obtained very poor score, poor score, and excellent.

Based on the data analysis, the t-statistical value 12.7 is higher than critical value 1.729 at the significant level 0.05 and the degree of freedom 19 with one tailed test. In other words, the song improves students' vocabulary at MAN 1 Halmahera Utara. The total score of pretest is 1.178 and the total score of posttest is 1.502. That result proofs that English song may influence their vocabulary to be improved.

The result of conducting result is based on Jolly in Millington's statement (2011: 136) that using songs can also give learners the opportunity to acquire a better understanding of the culture of the target language. It is also based on the experience when the researcher gave the treatment where the students' vocabulary were improved every steps of treatment.

\section{Conclusion}

Based on the result of the data analysis and the discussion in the previous chapter, it can be concluded that the improvement of the first students at Madrasah AliyahNegeri 1 Halmahera Utara in vocabulary through English song is significant.

This is supported by statistical data which show that the mean score in the posttest is higher than pretest. Posttest (75.1) is greater than in Pretest (58.9) and t-test (12.7) exceeds the ttable (1.729). It means that $\mathrm{Hi}$ was accepted and $\mathrm{H} 0$ was rejected because there is a significant difference between students posttest and pretest scores. 


\section{REFERENCES}

Alqahtani, Mofareh. 2015. The importance of vocabulary in language learning and how to be taught. Saudi Arabia: King Khaled Academic. Accessed on October $6^{\text {th }} 2017$

Djouadselma. 2015. The influence of using audio books in enhancing EFL students listening skill. ALGERIA. Biskra University

Fabon Borraz Alicia. 2013. 'Take it eassy': Using songs to teach English as a second language in primary school. Universidad de Larioja. Accessed on October $6^{\text {th }} 2017$

Fadrulrohman. 2017. Improving students' vocabulary mastery using song lyric (A classroom Action Research of the Seventh Grade Students of MTs Muhammadiyah 2 Karanganyar in the Academic Year 2016/2017”. Thesis. The state islamic institute of Surakarta

Hiebert and Kamil. 2005. Teaching and Learning, Vocabulary Perspectives and Persistent Issues,. Mahwah, New Jersey London.

Hutton. 2008. Three Tiers of Vocabulary and Education.Super Duper® Publications

Kothari C.R. 2004. Research Methodology, Methods and techniques, New Delhi: Ansari Road.

L.R.Gay. 2012. Education Research.America : late of Florida International University Lynch and Anderson. 2012. English Language Teaching Centre, University of Edinburgh.

Milington. T. Neil. 2011. Using song effectively to teach English to young learner. Japan: Ritsumeikan Asia Pacific University. Accessed on October $6^{\text {th }} 2017$.

Novia Windi. 2010. Basic English Grammar. Bandung: Gama press.

Pikulski John J. and Templeton Shane. 2013. Teaching and Developing Vocabulary: Key to Long-Term Reading Success. Accessed on October $6^{\text {th }} 2017$.

Rodriguez Maria. 2012. The importance of teaching listening and speaking skill.Rusia.Faculty of education.

Rusydah. 2015. The Effectiveness of Songs to Increase Students'Vocabulary; A Quasi Experimental Study at the Second Grade Students of SMP Al Huda Jakarta.Syarif hidayatullah state islamic university jakarta

Sevik Mustafa. 2012. Teaching listening skills to young learners through "listen anddo" songs. Turkey: English teaching Forum. Accessed on October $6^{\text {th }} 2018$.

Sugiono. 2016. Metode Penilitian Kuantitatif, Kualitatifdan $R \&$ \& Dandung: Alfabela.

Shin Kang Johan.2017. Get up and sing! get up and move! Using songs and movement with young learners of English.United states Accessed on October $6^{\text {th }} 2017$

Thornburry Scott. 2002. How to teach vocabulary. England: Longman.

Treasure, Julian. 2013. Conscious Listening. England. Annual Meeting Proceedings. 